\title{
A Comparison of the Statutory Provisions of the United Kingdom (UK) Companies Act 2006 and Ghana's Companies Act 1963 (Act 179), to the Rule in Foss v Harbottle
}

\author{
Alhassan Salifu Bawah \\ Business School, University of Education, Winneba, Ghana \\ Email: saliba101@yahoo.com
}

How to cite this paper: Bawah, A. S. (2019). A Comparison of the Statutory Provisions of the United Kingdom (UK) Companies Act 2006 and Ghana's Companies Act 1963 (Act 179), to the Rule in Foss v Harbottle. Beijing Law Review, 10, 153-167. https://doi.org/ 10.4236/blr.2019.101009

Received: January 7, 2019

Accepted: March 1, 2019

Published: March 4, 2019

Copyright $\odot 2019$ by author(s) and Scientific Research Publishing Inc. This work is licensed under the Creative Commons Attribution International License (CC BY 4.0).

http://creativecommons.org/licenses/by/4.0/ (c) (i) Open Access

\begin{abstract}
This paper adopts the comparative approach in its bid to compare the exceptions to the rule in Foss $v$ Harbottle $e^{1}$ under the statutory provisions of the UK Companies Act 2006 (CA 2006), and Ghana's Companies Act 1963 (Act 179). The rationale is to critically examine the differences and commonalities of the Companies Acts of both the UK and Ghana. The article argues that minority shareholders in Ghana are given more protection in terms of the avenues opened to them to bring actions against the company or the controlling majority shareholders as compared to what pertains in the United Kingdom.

\section{Keywords}

Companies Act 2006 and Insolvency Act 1986, Both of the UK, Companies Act 1963 (Act 179) of Ghana, Minority Shareholder Protection, Unfairly Prejudicial Conduct, Derivative Action, Just and Equitable Winding up, Shareholder Remedies, Representative Action
\end{abstract}

\section{Introduction}

The rule in Foss $v$ Harbottle is widely acknowledged as the deepest mystery of company law, and to a greater extend, of great practical importance to lawyers. It is important for a lawyer to be able to decide whether the client's claim would be heard by the court, and proceed to determine whether the client's claim falls under any of the exceptions to the rule in Foss $v$ Harbottle, that is, in cases where the claim concerns a company's affairs by a member. The common law excep-

${ }^{1}[1843] 2$ Hare 461. 
tions to the rule in Foss $v$ Harbottle, appear to be woefully inadequate. Therefore, most jurisdictions, the UK and Ghana included, statutorily provided exceptions to the rule. It is as a result of this current and continuing debate regarding the adequacy or inadequacy of the statutory provisions to the exceptions to the rule in Foss $v$ Harbottle, thus, minority shareholder protection that gave rise to this comparative study as a matter of necessity.

Section 1 focuses on the introduction, background to the study and literature review. Section 2 examines the statutory exceptions provided under the $U K$ Companies Act 2006 and the UK Insolvency Act 1986 to the rule established in Foss $v$ Harbottle, and proceeds to offer some criticisms. Under Section 3, the various protective measures devised by Ghana's Companies Act 1963 (Act 179) in respect of safeguarding the minority shareholder are examined, and this is followed by a conclusion.

\subsection{Literature Review}

As a general rule, individual members of a company do not have the right to sue to compel a company to conform to its articles of association and memorandum of association, referred to as the Regulations under the Companies Act 1963, (Act 179) of Ghana, thus suit against the company, or to enforce a claim belonging to the company, that is, suit on behalf of the company. The common law position is that if a member is dissatisfied with a decision of the board of directors or the majority of shareholders and brings an action in court, the company can properly and successfully object to the member's standing to sue, or the court, whether on the application of the company or on its own motion, may stay proceedings. The common law takes the position that even if there has been an irregularity or breach of the Regulations (articles of association and memorandum of association), so long as the irregularity or breach can be redeemed by the passing of an ordinary resolution, the aggrieved member is potentially, if not in fact, deprived of the right to successfully sue.

The limitation on the member's or minority's right to sue is known as the rule in Foss $v$ Harbottle. In this case, two shareholders in a company incorporated by statue (Victoria Park Co.), sued the company's five directors and others, alleging that the property of the company had been misapplied and wasted and that certain mortgages were improperly given over the company's property. The plaintiffs sought an order for the defendants to render account and for the appointment of a receiver. The Court of Chancery declined to intervene in a matter that the company could settle for itself or regularize if an irregularity existed. It was the company itself, which, prima facie, had the sole right to sue for wrongs done to it.

Wigram V-C reasoned that it would be an exercise in futility for the court to do what the company could easily and validly undo. He stated that: "How then can this court act in a suit constituted as this is, if it is to be assumed, for the purposes of argument, that the powers of the body of the proprietors are still in existence, and may lawfully be exercised for a purpose like that I have suggested? 
Whilst the court may be declaring the acts complained to be void at the suit of the present plaintiffs, who in fact may be the only proprietors who disapprove of them, the governing body of the proprietors may defeat the decree by lawfully resolving upon the confirmation of the very acts which are the subject of the suit. The very fact that the governing body of proprietors assembled at the special general meeting may so bind even a reluctant minority is decisive to show that the frame of this suit cannot be sustained whilst that body retains its functions ..."

In short, it was the court's view that so long as the company could confirm or avoid the impugned matter, shareholders could not sue the directors personally, or sue in the company's name in respect of the impugned matter. In dismissing the suit, Wigram V-C went on to say that: "I am of the opinion that this question-the question of confirmation or avoidance-cannot properly be litigated upon this record, regard being had to the existing state and powers of the company, and therefore that part of the bill which seeks to visit the directors personally with the consequences of the impeached mortgages and charges, the benefit of which the company enjoys, is in the same predicament as that which relates to the other subjects of complaint. Both questions stand on the same ground, and, for the reasons which I stated in considering the former point, these demurrers must be allowed."

The rule in Foss $v$ Harbottle has been widely applied in Ghana. In Appenteng \& Others $v$ Bank of West Africa Ltd. \& Others, ${ }^{2}$ the plaintiffs sued in their capacity as shareholders for negligent advice given by the Bank to a company, thus Mpotimma Ltd. They alleged that they had suffered loss which was personal and individual to them. It fell to the High Court to decide whether they had standing to institute the action. The applicability of Foss $v$ Harbottle was not in issue, but whether as a matter of law, the plaintiffs fell within any of the exceptions to permit them to sue. Ollenu J stated that: "Again on the principle laid down in Foss $v$ Harbottle and Edwards $v$ Halliwelp that to redress a wrong done to a company or to recover money or damages due to it the action must be brought by the company itself. Counsel for the plaintiff submitted that in this case the corporate wrong has affected the individual rights of shareholders therefore comes within the exceptions to the general principle". ${ }^{4}$

While accepting the statement of the law, Ollenu J however rejected the contention that the plaintiffs fell within an exception in the instant case. The court held that an individual right, the invasion of which will give a shareholder a cause of action for wrong done to the corporate body, must be a legal right, a right which is enforceable at law. It is true that the purpose with which a shareholder invests his money in a company is that the company should be a going concern and be able to declare profits and pay dividends. But a shareholder has no legal right that a company should always be a going concern. If the company 
should make profits and pay dividends, good luck to him, if it should declare loss and be unable to pay dividends then that's just too bad, he cannot sue anyone to compel profits to be declared. He has a legal right that he should be paid a share of the profits proportionate to his investment, and he can enforce payment of that share to him. It follows from this that loss of business interests and yearly profits and dividends do not constitute an invasion of any legal rights of the plaintiffs (shareholders of Mpotimma Ltd.). As a result, the plaintiffs did not come within the exception to the general principle; they had no claim.

The rule in Foss $v$ Harbottle which limits the individual's right to sue the company for various decisions the company may have taken, has been justified on several grounds. The first justification is the corporate status argument, namely, the existence of the separate and distinct status of the company. As such, the company alone should have status to inflict or suffer injury and it alone can sue and be sued, not aggrieved members for or against it. Secondly, there is the majority rule justification, namely, that one has to defer to the decision of the majority, despite one's difference therewith. As such, if the majority of directors or shareholders, through ordinary resolution have, or can take certain measures, these measures taken or proposed should be respected. Thirdly, there is judicial reluctance in making business decisions or interfering with business policies. Courts do not wish to second-guess the propriety or soundness of business decisions that have been made, or remedied, in compliance with statutory provisions and the Regulations. It is not the court's function to make management decisions or formulate business policies in place of the board of directors or other business decisions resolved by the majority of members, as the case may be. In addition, the courts will not make orders in vain. So long as any defect can be readily remedied by ordinary resolution, it is actually or potentially fruitless for judicial intervention. For the foregoing reasons, there are indeed strict limits on minority directors', members', and minority members' right to sue on behalf or against the company.

However, just as there are exceptions to almost every rule, there are exceptions to the rule in Foss $v$ Harbottle. The exceptions to the rule in Foss $v$ Harbottle are set out in Edwards $v$ Halliwell. The exceptions grant a member the right to sue a company in four circumstances, namely: to protect personal rights; to remedy illegal or ultra vires acts; where special majorities are required; and where fraud is perpetrated on the minority.

\subsection{Shortcomings of the Exceptions to the Rule in Foss $v$ Harbottle}

1) Suit to protect personal rights: A member does not have an absolute right to sue. In seeking to bring an action under this exception to the rule in Foss $V$ Harbottle, there are a couple of hurdles to overcome. First, the bar on enforcing so-called "outsider" rights conferred on a member by the articles of association. This hurdle encompasses the difficulties surrounding the enforceability of rights purportedly conferred on a member by the articles of association and in addi- 
tion, the distinction between insider rights, which are enforceable by virtue of the statutory contract, and outsider rights which, traditionally at least, are viewed as not enforceable. Secondly, in MacDougall $v$ Gardiner, ${ }^{5}$ the Court of Appeal reasoned that, if every irregularity could be litigated by a member, "then if there happens to be one cantankerous member, or one who loves litigation, everything of this kind (as on the facts) will be litigated".

2) Illegality and ultra vires the company: A careful analysis of case law indicates that the courts are not consistent as to what actually constitute "ultra vires the company". Each action brought by a minority member will depend on the circumstances and the particular judge, and this does not put the mind of the minority shareholder at rest when contemplating legal action to seek redress under the illegality and ultra vires the company "so-called" exception to the rule in Foss $v$ Harbottle.

In Prudential Assurance Co Ltd $v$ Newman Industries Ltd. (No 2), ${ }^{6}$ the UK Court of Appeal explained that where the wrongful act in issue is ultra vires the company, the rule does not operate because the majority of members cannot ratify the transaction. A minority member can therefore only challenge an action which would be ultra vires the company, in circumstances where the agreement has not been concluded. Furthermore, in Smith ${ }_{V} \operatorname{Croft}$ (No 2), ${ }^{7}$ it was held that, an individual shareholder could bring a personal action to restrain the company from acting in a certain manner because it infringed his personal right as an investor to have the business conducted in accordance with the memorandum and the articles of association. In Gray $v$ Lewis, ${ }^{8}$ it was held that where the shareholder is seeking to recover a loss suffered by the company as a result of a transaction actually entered into, the action will fail if he does not satisfy the requirement of wrongdoer control. This is because the wrong is done to the company directly, and so the company is the proper claimant (Dignam \& Lowry, 2009: p. 181). However, it is competent for the company to decide not to recover property which has been transferred ultra vires, provided the decision is taken in good faith, and in the company's interest (French, Mason, \& Ryan, 2010-2011: p. 563).

It is clear from the above that the courts are not settled on issues that actually constitute ultra vires the company.

3) Where a special majority is required: This appears not to be a true exception to the rule in Foss $v$ Harbottle, on the basis that it is the company that has done something wrong, rather than being the victim of a wrong. The exception also overlaps with the first exception (where a member's personal rights have been infringed), in that; a shareholder has a personal right to have the articles of association observed. Thus, where the conduct in question is an attempt to alter a $C A 2006$ s. 33 contract by not following a procedure requiring a special resolution, the court may grant an injunction to an individual member prohibiting the

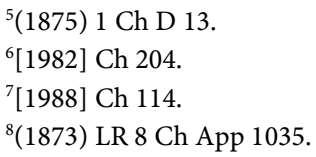


majority from acting in breach of the article in question (Quin \& Axtens Ltd $v$ Salmon). ${ }^{9}$ The decision in Edwards $v$ Halliwell itself can be explained on the basis that the two members in question had a personal right not to have their subscriptions increased without the proper procedure being followed (Dignam \& Lowry, 2009: p. 182).

4) Where fraud is perpetrated on the minority: This is where fraud has been perpetrated against the company by those who "hold and control the majority of shares in the company and will not permit an action to be brought in the name of the company", per Lord Davey in Burland $v$ Earle. ${ }^{10}$ The judges have not set precise parameters on the meaning of fraud in this context. In Estmanco (Kilner House) Ltd. v Greater London Council, ${ }^{11}$ Megarry V-C said that: "The essence of the matter seems to be an abuse or misuse of power" and that the term carries its wider equitable meaning. It therefore covers conduct that is plainly improper but not necessarily deceitful.

Templeman J in Daniels $v$ Daniels, ${ }^{12}$ took the view that the exception would permit the minority to sue even in the absence of fraud where directors have abused their powers, "intentionally or unintentionally, fraudulently or negligently, in a manner which benefits themselves at the expense of the company".

The judge concluded that fraud should extend to cases of self-serving negligence which is tantamount to misappropriation of company assets. Turning on to Prudential Assurance Co Ltd v Newman Industries Co Ltd (No 2) again, Vinelott $\mathrm{J}$ opined that the requirement of 'fraud' would be satisfied where the interested shareholders use their voting power to stultify any proceedings being taken against them.

Fraud has therefore been held to include the expropriation of company property, thus Cooks $v$ Deeks, ${ }^{13}$ where the Privy Council held that the directors held the benefit of the contract on constructive trust for the company (Dignam \& Lowry, 2009: p. 184). There has also been some debate over whether de facto control is sufficient or de jure control must be established to satisfy the element of "wrongdoer in control". The Court of Appeal took a realistic view of the meaning of "control", noting that it should not necessarily be limited to de jure control, but that it could encompass the situation where the majority vote is made up of those votes "cast by the delinquent himself plus those voting with him as a result of influence or apathy".

Despite the wider definitions given to fraud and wrongdoer in control above, which appeared to have given the minority much room to seek redress under this heading from a stand point of view, the "control" requirement was diluted by Knox J in Smith v Croft (No 2). Knox J stated that: "If the majority of the remaining shareholders who were independent of the wrongdoers, termed 'the

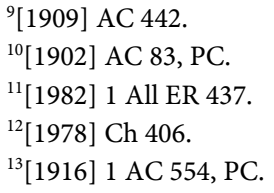


majority inside the minority' did not desire the proceedings for 'disinterested reasons', the single member seeking to sue would be denied locus standi'. This decision is not in any way helpful to the minority member.

Due to the above and other wide ranging criticisms of the common law exceptions to the rule in Foss $v$ Harbottle, the UK and Ghana, through CA 2006 and Act 179 respectively laid down further exceptions to the rule in Foss $v$ Harbottle. These statutory exceptions, which are the main focus of this study, are comparatively examined next.

\section{Statutory Exceptions under the UK Companies Act 2006 to the Rule in Foss $v$ Harbottle}

The most important of these include: Action for "unfairly prejudicial conduct" under $C A$ 2006, section (s) 994. The second is a Derivative Action under $C A$ 2006, sections (ss) 260-264, and finally, "Just and equitable winding up" under the Insolvency Act (IA) 1986, s. 122.

\subsection{Unfairly Prejudicial Conduct under s. 994 of UK Companies Act 2006}

In respect of "unfairly prejudicial conduct", a member can bring an action under $C A 2006$ s. 994 (1). The requirement under this section that the conduct is not only prejudicial to the rights of shareholders but also that it is unfairly prejudicial, is important as anyone who losses a vote could claim that their interests have been prejudiced, but there is clearly nothing wrong with losing a vote (Taylor, 2009: p. 92). Neil LJ stated in Re Saul D Harrison and Sons Plc ${ }^{14}$ that, the words "unfairly prejudicial are general words and should be applied flexibly to meet the circumstances of the particular case". The most common remedy sought is an order that the majority purchase the minority's shares at a price that reflects their proportion of the company's value (Sealy \& Worthington, 2013: p. 710).

\subsection{Criticisms of s. 994 (1) of the UK Companies Act 2006}

The most common criticism under this part is that a controlling majority of members have unfairly prejudiced the minority.

A petition for relief of unfairly prejudicial conduct of a company's affairs may be presented by a person who joined the company in the knowledge that its affairs were being conducted in the manner complained of (Bermuda Cablevision Ltd v Colica Trust Co Ltd.). ${ }^{15}$

Furthermore, a nominee shareholder, holding shares as a bare trustee, may petition under s. 994, because the interests of such a shareholder include the economic and contractual interests of the beneficial owners of the shares. This was the position in Atlasview Ltd $v$ Brightview Ltd. ${ }^{16}$ The rule that he who comes

\footnotetext{
${ }^{14}$ [1995] 1 BCLC 14.

${ }^{15}$ [1998] AC 198.

${ }^{16}[2004]$ EWHC 1056 (Ch).
} 
to equity must come with clean hands does not apply to s. 994. Thus, a petitioner's own misconduct is not in itself a reason for rejecting the petition, though it may show that the petitioner was not unfairly prejudiced or may affect the remedy given by the court (Re London School of Electronics Ltd.). ${ }^{17}$

The provision does not also give a former member standing to petition $(\operatorname{Re} A$ Company). ${ }^{18} \mathrm{~A}$ member who cannot show prima facie evidence of standing will not be allowed to petition, thus, the question of standing must be settled first ( $R e$ Quickdome Ltd.). ${ }^{19}$ It should be noted that no limitation period applies to a petition for the relief of unfairly prejudicial conduct of a company's affairs. However, the court has discretion whether to grant the relief. It was held in Re Grandactual Ltd., ${ }^{20}$ that no court would grant relief for events which happened nine years ago and which the petitioner had co-operated in.

A further criticism of s. 994, relate to the issue of cost and delay. The unreported case of Re Freudiana Music Co Ltd (1993), occupied 165 days of court time. After the case was decided, there was a lengthy battle as to who should pay costs (Re Freudiana Holdings Ltd.). ${ }^{21}$ Lawyers presenting a case on unfair prejudice in a company often deal with the whole history of the company in detail, so as to build up an overall picture of the prejudice, and this is countered by equally extensive evidence and cross-examination from the other side. The result can easily be that costs exceed the value of the assets being fought over, as was the case in Re Elgindata Ltd., ${ }^{22}$ where costs of $£ 320,000$ were incurred arguing over shares worth a mere $£ 24,600$.

As a result of the above inherent problems of costs and delay associated with a petition of unfairly prejudicial conduct, in its report titled: Shareholder Remedies ( Law Com No 246, Cm 3769), the UK Law Commission considered ways of reforming unfair prejudice proceedings. Its principal recommendation among others was that, the problems of excessive length and costs should be dealt with primarily through active case management by the courts. ${ }^{23}$

\subsection{Derivative Claim under Sections 260-264 of the UK Companies Act 2006}

The second statutory exception to the rule in Foss $v$ Harbottle, is a derivative claim under $C A 2006$ ss. 260-264. CA 2006 s. 260 (1) defines derivative claims as proceedings brought by a member of a company in respect of a cause vested in the company and seeking relief on behalf of the company. A derivative claim maybe brought in the name of the company. This existed for many years as a possible remedy under the common law, but the scope for such actions have now increased dramatically with $C A 2006$ under the statutory provision for de-

\footnotetext{
${ }^{17}$ [1986] Ch 211.

${ }^{18}$ (No 00330 of 1991) [1991] BCLC 597.

${ }^{19}$ (ChD 1988) [1988] BCLC 370.

${ }^{20}$ [2005] EWHC 1415 (Ch), [2006] BCC 73.

${ }^{21}$ (1995) The Times, 4 December.

${ }^{22}$ [1991] BCLC 959.

${ }^{23}$ https://www.lawcom.gov.uk/project/shareholder-remedies (accessed 7th July 2018).
} 
rivative actions (Taylor, 2009: p. 94). The grounds for bringing a derivative claim are laid down under s. 260 (3), which has some significant facets.

Claims against directors for breach of their duties owed to the company (now codified in Part 10 of $C A$ 2006) fall within the scope of $C A 2006$ s. 260 (3), which is wider than the common law action it replaces in so far as it is in respect of a cause of action arising from an actual or proposed act or omission involving negligence, default, breach of duty, or breach of trust by a director (Judge, 2010-2011: pp. 151-152).

Significantly, under the statutory procedure, there is no need to demonstrate "fraud on the minority" and "wrongdoer control", so that even where the defendant director has acted in good faith and has not gained personally, a claim can nevertheless be brought (Pavlides $V$ Jensen). ${ }^{24}$ Section 260 (3) also makes it clear that a derivative claim may be brought, for example against a third party who dishonestly assists a director's breach of fiduciary duty or one who knowingly receives property in breach of a fiduciary duty. Furthermore, it is immaterial whether the cause of action arose before or after the person seeking to bring or continue the derivative claim became a member of the company (s. 260 (4)) (Dignam \& Lowry, 2009: p. 187).

\subsection{Criticisms of ss. 260-264 (Derivative Claim)}

Section 261 of $C A 2006$ provides that, once a derivative claim has been brought, the member must apply to the court for permission to continue it. Section 263 (2) sets out the criteria which the court must take into account when determining whether to grant permission to a member to continue a derivative claim. This criterion, it is argued, is a bar to a derivative claim proceeding. The requirement that the court should take into account the importance that a director acting in accordance with the duty to promote the success of the company would attach to the claim appears to dispense with the old common law prerequisite of "wrongdoer control". The list of factors to be taken into account for determining the refusal of permission is supplemented by s. 263 (3) which sets out the factors which the court must, in particular, take into account when exercising its discretion to grant permission to continue a derivative claim.

Comparing the language of ss. 261-264 with the common law rules it replaces shows that there is little or no change of emphasizes in terms of formulation. The focus of the rule laid down in Foss $v$ Harbottle and its jurisprudence was on prohibiting claims unless one of the exceptions to the rule was satisfied. The statutory language similarly proceeds from the rather negative standpoint that the court must dismiss the application or claim in the circumstances specified in ss. 261 (2), 262 (3), 263 (2)-(3) and 264 (3).

To compound the inherent difficulties associated with derivative claims, legal aid has never been available to those seeking to bring a derivative action and so in Wallersteiner V Moir (No. 2), ${ }^{25}$ Lord Denning MR expressed the minority 
view that contingency fees could be used to fund such actions. The $C A 2006$ further failed to make provision for the remedies available in a derivative claim.

In addition to the above hindrances to derivative claims, where a company goes into liquidation, the court will not allow a derivative action to be brought or continued because the liquidator then has the statutory power to litigate in the company's name (IA 1986, s. 165 (3), s. 167 (1) and Schedule 4, paragraph (para) 4. The position was succinctly stated by Walton J in Fargro Ltd. $v$ Godfroy. ${ }^{26} \mathrm{Al}-$ so, in Portfolios of Distinction Ltd. $v$ Laird, ${ }^{27}$ Launcelot Henderson QC, sitting as a Deputy High Court Judge, considered at length the judgment of Peter Gibson LJ in Barrett $v$ Duckett, ${ }^{28}$ and stressed that in determining whether to permit a derivative action to continue, the shareholder must establish a positive case for being allowed to sue on behalf of the company, and that the shareholder would be allowed to do so only if two conditions are satisfied, namely that, he is bringing the action bona fide for the benefit of the company, and secondly, that no other adequate remedy is available. This requirement only goes to further compound the woes of the minority shareholder in the quest to protect his rights.

\subsection{Just and Equitable Winding up under Section 122 of UK Insolvency Act 1986}

The final statutory exception to the rule in Foss $v$ Harbottle in the UK, is an application for the "just and equitable winding up" of the company under s. 122 of the Insolvency Act 1986 (IA 1986), as an option of last resort. Obviously, this is a very serious course of action as it means that an otherwise successful company may be forced to cease trading. For this reason, the court will only make such an order in exceptional circumstances.

In Re Bleriot Manufacturing Aircraft Co Ltd. ${ }^{29}$ Neville J stated that, the words "just and equitable, are words of the widest significance, and do not limit the jurisdiction of the court to any case. It is a question of fact, and each case must depend on its own circumstances".

A contributory petitioning under $I A$ 1986, s. 122 (1) (g) may rely "upon any circumstances of justice or equity which affect him in his relation with the company, or ... with the other shareholders", per Lord Wilberforce in Ebrahimi $V$ Westbourne Galleries Ltd. ${ }^{30}$

Unless the articles of association of a company provide otherwise, a member cannot make it wind up voluntarily other than by obtaining a three-quarters majority at a general meeting. A person must accept, on joining a company that leaving the company is subject to this fundamental restriction. A contributory presenting a just and equitable petition is claiming that it is just and equitable to waive this restriction. The essential question on a contributory's petition, "is whether members who do not desire to stay in a company should be entitled to

\footnotetext{
${ }^{26}$ [1986] 1 WLR 1134.

${ }^{27}$ [2004] All ER 09, CA.

${ }^{28}$ [1995] BCLC 243, CA.

${ }^{29}(1916) 32$ TLR 253.

${ }^{30}[1973]$ AC 360.
} 
be released", per Harman J in Re A company No $003701987 .^{31}$

\subsection{Criticism of $s .122$ (1) (g)}

It can be observed from the above that unless the circumstance is exceptional, the minority shareholder is unlikely to succeed in an action against the company under s. 122 (1) (g) of the Insolvency Act 1986. It might not only be difficult, but highly unlikely for a contributory to obtain a three-quarters majority at a general meeting to support his claim under s. 122 (1) (g). The discussion will now move to minority shareholder protection under Ghana's Companies Act 1963, (Act 179).

\section{Minority Shareholder Protection in Ghana}

In Ghana, Case Law, and the provisions of Act 179, appear to have given minority shareholders, much room to bring actions against companies than $C A 2006$ of the UK.

Minority shareholders have a limited right to sue a company and compel it to adhere to its Regulations (Memorandum and Articles of Association), referred to as suit against the company, or sue to enforce the company's claim, thus suit on behalf of the company.

In Appenteng \& Others $v$ Bank of West Africa Ltd\& Others, the Court held that the claimant be paid a share proportionate to his investment. Also, in Okudjeto \& Others V Irani Brothers \& Others, ${ }^{32}$ the Court on the application of minority shareholders, restrained the majority who perpetrated fraud on the company by appropriating to themselves, money, property and other advantages which belonged to the company.

\subsection{Representative Actions}

Section 21 of Act 179, provides for Representative Actions. This is where the plaintiff seeks to enforce a right that he enjoys by virtue of being a member of a class, or seeks relief because he suffers burdens as a member of a certain class, or he seeks to enforce compliance with the company's Regulations.

Usually, the registration of the Regulations of a company has three effects. First, the registered Regulations constitute a contract under seal between the company and its members and officers, and between the members and the officers themselves.

Furthermore, where the Regulations empower an individual to appoint or remove any director or officer of the company, such a person is vested with these powers of appointment, whether such a person is a member/officer of the company or not.

As a result of the above provisions, the claimant, being a member or officer of the company, who brings an action to enforce compliance of the Regulations, shall do so on his own behalf and on behalf of the other members and officers 
affected by the breach of the Regulations, excluding the other members and officers, defending the suit. Actions by members or officers, whether against each other or the company, are required to be in Representative form. Also, any suit by a member to enforce or challenge a third person's right to appoint or remove a director or officer, must be in a Representative capacity.

Representative actions are available in a variety of instances. Where a shareholder or creditor seeks to obtain a court order for an injunction to restrain a company from paying dividends or making a return or distribution of any of the company's assets, contrary to s. 71 (1) of Act 179; or where the shareholder or creditor seeks from the court an order for the restoration of any dividend paid, asset return, or assets distributed, under s. 71 (3) of Act 179, all such actions are required to be initiated by the shareholder or creditor in a Representative capacity for all members of his class (Bondzi-Simpson, 2009: p. 275).

A Representative action is further required in instances where a debentureholder institutes legal proceedings to enforce the security of a series of debentures of which he holds part. The action should be on behalf of all debentureholders of the series that he seeks to enforce.

Finally, under s. 210 (1) and (3) of Act 179, suits brought by members against directors to enforce liabilities, or restrain threatened breach of duty by directors, or recover from the directors any property of the company, ought to be in a Representative capacity.

Representative actions, are governed by s. 324 of Act 179. The combined effects of the rules laid down in s. 324 is to avoid duplicity of actions in respect of the same matter, by various persons entitled to make the claim or claims in question. The benefits of Representative actions, accrue to all persons being represented.

\subsection{Criticism of Representative Actions}

Where the litigant (s) sue without the permission of the class, and an assurance of contribution by them for the costs associated with the suit, the litigant (s) alone will bear the cost of the suit, notwithstanding the fact that the benefits would have been for all.

\subsection{Injunction or Declaration in the Event of Illegal or Irregular Activity under s. 217 of Act 179}

Another exception to the rule in Foss $v$ Harbottle provided in Ghana's Act 179, is the window of opportunity for a member to apply to the court for an injunction to restrain the company from doing any act or entering into any transaction which is illegal, or beyond the powers or capacity of the company, or which infringes the provisions of the Regulations, or from acting on any resolution not properly passed in accordance with Act 179 and the Regulations.

\subsection{Criticisms of s. 217 of Act 179}

Upon an application by a member for an injunction and or a declaration under 
s. 217, the court may order that the member post security for the company's cost, and the court may also direct that the application is heard in chambers. The essence for an application for security for costs is to give the defendant peace of mind in instances where the application brought by the member is unmeritorious, frivolous or vexatious. The defendant's costs associated with defending the suit can then be defrayed from the moneys posted as security. The fact that the minority member may be required by the court to post security, which he is likely to lose, may deter minority members from instituting actions under s. 217 of Act 179. Furthermore, only members may apply for a section 217 remedy.

\subsection{Remedy against Oppression under s. 218 of Act 179}

A final statutory exception to be considered is the "remedy against oppression". This covers twelve instances, each of which entitles a member or debentureholder of the company to apply for the appropriate judicial relief. Some of these instances are: conduct of the company; powers of directors; act done or threatened; resolution passed or proposed; disregard of proper interests; oppressive; unfairly discriminatory; and unfairly prejudicial. In Mahama v Soli \& Another, ${ }^{33}$ oppression was considered by Akpaloo JA to comprise conduct that was "burdensome, harsh and wrongful".

A wide range of remedies are available under s. 218. These include, but not limited to: directing an act; prohibiting an act; altering or adding to the company's Regulations, etc. Once a case is made out under s. 218 (1), that is directing an act, it may be just and equitable to wind up the company. However, since winding up constitute dealing a death-blow to the company, courts are slow in making winding up orders. Osei-Hwere JA in Asafu-Adjaye v Agyekum, ${ }^{34}$ described an order to wind up or dissolve a company, "as a cure by sledge-hammer".

\subsection{Criticisms of s. 218 of Act 179}

The phrase remedy against oppression, is misleading. An act of oppression can, but does not necessarily entitle an applicant to a remedy under s. 218. In Pinamang $V_{\text {Abrokwa }}{ }^{35}$ the Court of Appeal held that an applicant who seeks a section 218 remedy, "must adduce evidence seeking to show a chain of events and occurrences of harsh and burdensome conduct which continued up to the date of presentation of the petition". This requirement to some extent, may be burdensome on the applicant.

\section{Conclusion}

To draw a curtain on this study, it is of paramount importance to emphasize that there is no perfect law anywhere in the world. With this as a yardstick, one is therefore on the "hunt" for a law with minimal defects when undertaking a comparative statutory study as is the case in this research. The statutory provi-

${ }^{33}$ [1977] 1 GLR 215 (CA).

${ }^{34}[1984-86] 1$ GLR 383.

${ }^{35}$ [1991] 2 GLR 384 (CA). 
sions laid down by $C A 2006$ and $A c t$ 179, primarily came into being as a result of certain inherent flaws in the common law exceptions to the rule in Foss $v$ Harbottle. Upon an examination of the provisions of $C A 2006$ relating to minority shareholder protection as seen above, it is evident that it accords the minority shareholder, an improved protection than the common law. For example, the provision of legal aid, will lead to a significant reduction of criticisms of s. 994 of $C A 2006$ (unfairly prejudicial conduct).

With regards to a derivative claim under ss. 260-264 of $C A 2006$, it is submitted that its wording is similar to the common law exception it purports to replace, therefore, it offers no extra protection to the minority shareholder than the common law. Also, under s. 122 (1) (g) of the Insolvency Act 1986, the requirement that the circumstance of the minority shareholder's claim is exceptional, appears not to be helpful.

Suffice is to say that the avenues opened to members to sue under representative actions of s. 21 of $A c t$ 179, are broad and straightforward. The major criticism of this section being that the litigant(s) alone will bear the cost of the suit, even though the benefits would be for all if successful, is easily overcome by seeking the permission of all concerned members before instituting the claim.

On the issue of the likelihood of losing security posted in an action by a member for injunction or declaration in the event of illegal or irregular activity under s. 217 of $A c t$ 179, it is a well-established fact that profits go with loses, therefore, security posted before a case is heard, is nothing untoward or punitive. It is just a devise to sieve out frivolous and vexatious actions.

Finally, the holding of the Ghanaian Court of Appeal that an applicant who seeks a section 218 remedy, "must adduce evidence seeking to show a chain of events and occurrences of harsh and burdensome conduct which continued up to the date of presentation of the petition", is a requirement that any minority member who genuinely seeks protection under the section, should be able to meet. Cataloguing a chain of events and instances of harsh and burdensome conduct, may not be that "burdensome". Minutes of meetings could be of great help in this regard.

It is evident that Act 179 permits the individual the right to sue, thereby reversing the previous common law principle that barred a suit so long as the breach was capable of being remedied by an ordinary resolution, thus s. 217 (1). Furthermore, unless the company actually remedies a breach by passing a curative resolution, the individual's suit may succeed. The limitations on the individuals' right to sue in respect of various corporate acts, transactions and resolutions have therefore been eased somewhat by Act 179. It also appears that the Ghanaian courts have a "soft spot", for the minority shareholder when it comes to asserting his rights, than the UK courts, as evidenced in the discussion above.

\section{Conflicts of Interest}

The author declares no conflicts of interest regarding the publication of this paper. 


\section{References}

Bondzi-Simpson, P. E. (2009). Company Law in Ghana (2 $2^{\text {nd }}$ Edition). Accra: Avant Associates Limited.

Dignam, A., \& Lowry, J. (2009). Company Law: Core Text Series ( $5^{\text {th }}$ Edition). Oxford: Oxford University Press.

French, D., Mayson, S., \& Ryan, C. (2010-2011). Company Law (27 ${ }^{\text {th }}$ Edition). Oxford: Oxford University Press.

Judge, S. (2010-2011). Company Law (2 ${ }^{\text {nd }}$ Edition). Oxford: Oxford University Press.

Sealy, L., \& Worthington, S. (2013). Cases and Materials in Company Law (10 ${ }^{\text {th }}$ Edition). Oxford: Oxford University Press.

Taylor, C. (2009). Company Law: Law Express. Harlow: Pearson Education Limited. 